\title{
Mytilus edulis shell as a bioindicator of lead pollution: considerations on bioavailability and variability
}

\author{
B.P. Bourgoin \\ Trent University, Department of Environmental and Resource Studies, Peterborough, Ontario, Canada K9J 7B8
}

\begin{abstract}
The nacre of Mytilus edulis is introduced as an alternative to soft tissues for trace metal analyses in biological monitoring programs. The inner nacreous shell and soft tissues of mussels collected near a $\mathrm{Pb}$ smelter were analyzed for $\mathrm{Pb}$ and compared with the total- $\mathrm{Pb}$ content in suspended particulate matter (SPM). The results indicate that shells can provide an index of $\mathrm{Pb}$ bioavailability as the nacre- $\mathrm{Pb}$ levels were strongly correlated $(\mathrm{p}<0.001)$ with the tissue-Pb concentrations. Although nacre sequesters ca one tenth of the $\mathrm{Pb}$ measured in the tissues, the statistical variability associated with nacre- $\mathrm{Pb}$ levels is half that calculated for the tissues. Consequently, nacre-Pb levels offer a comparatively better relationship with the SPM Pb-content and also provide a significantly better spatial resolution. How other biophysical parameters such as mussel age, size, and littoral zonation may affect mussel $\mathrm{Pb}$ concentrations are also discussed.
\end{abstract}

\section{INTRODUCTION}

The molluscan capacity to magnify and integrate aquatic pollutants is considered to play a key role in monitoring environmental quality. As a convention, analytical data are expressed as the concentration of trace metals in the soft tissues of bivalves on a dry or wet weight basis $\left(\mathrm{gg} \mathrm{g}^{-1}\right)$. However, metal concentrations in bivalve soft tissues are associated with a high degree of inherent variability which often complicates attempts to detect changes resulting from anthropogenic activity (Gordon et al. 1980).

Although Comfort (1949) suggested $40 \mathrm{yr}$ ago that bivalve shells may act as receptacles for unwanted chemical species, shell trace-metal analyses have rarely been reported in monitoring programs. This is likely related to earlier studies suggesting that metal levels in shells were due to passive adsorption processes and hence, were not indicative of their bioavailability (Keckes et al. 1968, Romeril 1971). Unfortunately, these studies failed to recognize or analyze discrete structural components of bivalve shells.

This study evaluates the feasibility of using Mytilus edulis shells - particularly the nacreous layer - as a monitoring tool for $\mathrm{Pb}$ pollution. The relationships between $\mathrm{Pb}$ levels in the soft tissues and the nacreous shell layer as well as the statistical variability in both of these materials are investigated. Biotic parameters such as shell length, shell weight and mussel age are also examined to ascertain how they may affect the mussel's indicator ability. The terminology relating to shell structure throughout this study is that of Taylor et al. (1969).

\section{Shell secretion and trace metal uptake}

Although it is beyond the scope of this paper to cover all the details involved in bivalve anatomy and shell secretion, a minimum of background information is required to appreciate the results presented below. Simkiss \& Wilbur (1977) and Krampitz \& Graser (1988) give a more detailed review on the anatomical compartments and molecular mechanisms involved with biomineralization, respectively.

The bivalve shell is a complex organic/inorganic system consisting of 2 calcified valves covered by an outer organic layer, the periostracum. The periostracum's main role in marine epifaunal bivalves is to act as a support and substrate for the initial nucleation and crystal growth of the calcareous shell. This shell consists of calcium carbonate crystals and a small amount of organic matrix (ca $3 \%$ ) organized in 2 or more structural components. The Mytilus edulis shell 
has 2 structural components; an outer prismatic calcite layer and an inner nacreous aragonite layer. Like the shell, the mantle epithelium greatly overhangs the body, and it forms a large sheet of tissue lying beneath the valves. The mantle edge is divided into 3 folds in which the outer fold is responsible for shell secretion.

In short, shell secretion occurs within the extrapallial space in which the mantle epithelium secretes the extrapallial fluid. Aside from containing all the components for biomineralization (e.g. $\mathrm{Ca}^{++}, \mathrm{HCO}_{3}^{-}$, organic molecules) the extrapallial fluid may also contain heavy metals when present in the outer medium. The actual secretion/sequencing of the different structural shell components, i.e. periostracum layer $\rightarrow$ calcitic layer $\rightarrow$ nacreous layer, is determined by different regions of the mantle epithelium. In Mytilus edulis, the extrapallial space is effectively isolated from the outer environment (Chétail \& Krampitz 1982). Consequently, any trace metals actively incorporated within the shell matrix during shell growth must have been assimilated by the organism (Wilbur \& Saleuddin 1983).

Shell trace metal levels, therefore, should provide an index of their bioavailability. However, trace metals passively adsorbed to the shell surface cannot be differentiated from those incorporated within the shell matrix. It is therefore essential to choose a structural shell component which has not been exposed to either particulate or dissolved metal species in the water column. In Mytilus edulis shells, this restriction precludes the use of the periostracum and calcite layers, as the former is often partially eroded and exposes large portions of the calcite layer to the water column. Hence, as long as the degree of shell abrasion is low and the nacreous layer has not been exposed to the outer medium, it should essentially contain biologically deposited trace metals.

\section{Study area}

The refining of $\mathrm{Pb} / \mathrm{Zn}$ sulphide ores at Belledune Harbor and their shipping to international markets from Dalhousie Harbor (Canada) have contributed to high metal loadings in the coastal environment and has resulted in extensive shellfish closures over much of New Brunswick's north shore (inset, Fig. 1) Lead is introduced into the coastal environment either as $\mathrm{Pb}$ sulphide from windblown particles from ore stockpiles at Dalhousie Harbor (Fig. 1A) or from the smelter's aqueous effluent discharged to Belledune Harbor (Hildebrand 1984) The sulfuric acid produced during the refinement of the $\mathrm{Pb} / \mathrm{Zn}$ ores is used in combination with fluorapatite and ammonia to produce diammonium phosphate fertilizer (Fig. 1B). In November 1980, various improvements in waste treatment proces- ses at the Belledune smelter were introduced. Among these changes was the relocation of the smelter outfall from within the harbor out onto the coast (Fig. 1B).

The surface current regime within the Baie des Chaleurs is westerly, entering the Bay along the Quebec coast and exiting easterly along the New Brunswick shore (Legendre \& Watt 1970). The coastal currents are mainly due to the freshwater discharged by the Restigouche River and flow in a southeasterly direction along the New Brunswick shore (Loring et al. 1980). A clockwise gyre characterizes the water circulation within Belledune Harbor. This harbor has been described as a closed system where exchange between harbor and coastal flow, i.e. flushing, was limited to tidal flushing and diffusive effects only (Loring et al. 1980).

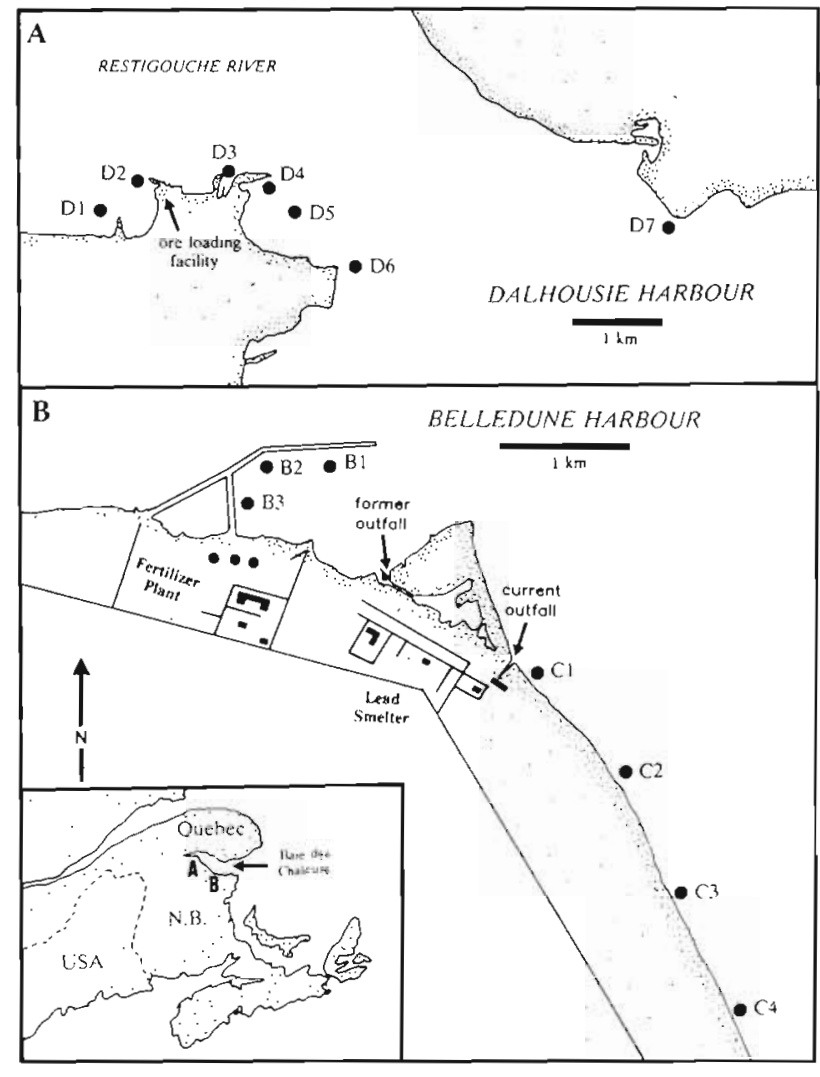

Fig. 1 Location of sampling sites in Dalhousie Harbor (D1 to D7), within Belledune Harbor (B1 to B3) and on the coast south of Belledune Harbor (C1 to C4)

\section{MATERIAL AND METHODS}

Sampling. During July 25 to 28, 1985, a total of 14 stations were sampled in the Dalhousie-Belledune region. Seven stations were established in Dalhousie; 6 in 
the harbor itself (D1 to D6) and 1 off the Quebec coast (D7, Fig. 1A). The remaining 7 stations were located near Belledune; 3 within the harbor (B1 to B3) and 4 coastal stations south of Belledune Harbor at $1000 \mathrm{~m}$ intervals (C1 to C4, Fig. 1B).

Suspended particulate material (SPM) was sampled by SCUBA using acid-cleaned polyethylene bottles (1). The bottles were opened ca $30 \mathrm{~cm}$ from the bottom during the divers' initial descent to avoid sampling resuspended sediments. The samples were filtered through pre-weighed Nucleopore filters $10.45 \mu \mathrm{m}$ pore size) within $48 \mathrm{~h}$ of collection. The residue-laden filters were maintained frozen at $-20^{\circ} \mathrm{C}$ pending analyses.

Mussels greater than $20 \mathrm{~cm}$ (shell length) were collected in nylon bags by divers who avoided any specimens anchored to metallic structures. Special attention was taken to select mussels from a single clump to ensure environmental homogeneity (Lobel et al. 1982). The conditions of the shells were examined immediately after collection and highly abraded or damaged shells were discarded. The selected mussels were allowed to depurate their gut content in ambient seawater for $48 \mathrm{~h}$ and stored frozen at $-20^{\circ} \mathrm{C}$ until required for analysis.

Bivalve age determination. Similar size mussels $(65$ $\pm 3 \mathrm{~mm}$ ) collected at Stns D3, B2 and C1 were selected for age determinations. Clean valves were dried sequentially in 50,75 and twice in $100 \%$ ethanol, prior to embedding in Spurr's resin (Spurr 1969). The embedded shells were sectioned along the antero-posterior axis with a diamond saw and prepared for acetate peels as outlined in Kennish et al. (1980). The acetate peels were then examined with a stereo microscope equipped with a scaled ocular lens to determine the number and thickness of the growth bands in the nacreous shell layer.

Growth bands defined as zones with alternating regions containing variable concentrations of organic material (Lutz \& Rhoads 1980), showed up as alternating light and dark layers within the nacreous shell layer. Lutz (1976) demonstrated that these patterns reflect annual cycles of growth in Mytilus edulis collected from temperate climates and could provide accurate age estimates of individual mussels. The term 'annual layer' has therefore been adopted in this study.

Analyses. Nucleopore filters were dried at $60^{\circ} \mathrm{C}$ and weighed. The concentration of SPM was calculated as the weight of the residue divided by the volume of filtered seawater. The SPM was digested in a mixture of aqua regia (Ultrex) and concentrated HF (Ultrex) and analyzed for $\mathrm{Pb}$ by atomic absorption spectroscopy (AAS) using a Perkin-Elmer 603 as outlined in Rantala \& Loring (1977).

Similar size mussels ( $65 \pm 3 \mathrm{~mm}$, shell length) were selected and thawed at room temperature. The bi- valves were shucked (taking care not to damage the inner shell) using stainless steel instruments, the tissues dried $\left(70^{\circ} \mathrm{C}\right)$, weighed and ground in an agate mortar. A total of 10 mussels per sampling station were analyzed separately. Approximately $200 \mathrm{mg}$ subsamples of each individual were digested with concentrated $\mathrm{HNO}_{3}$ (BDH, Aristar) in Teflon bombs (Borg et al. 1981)

The shells were cleaned of extraneous material e.g. sediments, with a nylon brush under running distilled water, dried at $70^{\circ} \mathrm{C}$ for $20 \mathrm{~h}$ and weighed. The cleaned shells were ashed in a muffle furnace at $400^{\circ} \mathrm{C}$ for $18 \mathrm{~h}$ after which the calcite and nacreous shell layers were separated (Bourgoin 1988), and weighed. Approximately $50 \mathrm{mg}$ of ashed nacre was lightly scraped from the inner growth surface of the nacre shell at a depth no greater than $0.1 \mathrm{~mm}$ to assure that only recently deposited material was collected. The nacre samples were then digested in concentrated $\mathrm{HNO}_{3}$ (BDH, Aristar), and made up to volume with double distilled deionized water (DDW).

The tissue and shell digests were analyzed on a Perkin-Elmer HGA 2100 graphite furnace, which was programmed as follows: drying time $20 \mathrm{~s}$ at $180^{\circ} \mathrm{C}$; charring time $20 \mathrm{~s}$ at $500^{\circ} \mathrm{C}$; atomizing time $13 \mathrm{~s}$ at $1800^{\circ} \mathrm{C}$; cleaning time $3 \mathrm{~s}$ at $2700^{\circ} \mathrm{C}$; wavelength 283.3 $\mathrm{nm}$; integration time $10 \mathrm{~s}$; background correction - on; sample size $10 \mu \mathrm{l}$. The furnace assembly was cleaned after every 20 determinations.

All mussel $\mathrm{Pb}$ concentrations $\left(\mu \mathrm{g}^{-1}\right)$ refer to dry weight of soft tissues and nacreous shell. Significant differences in mussel- $\mathrm{Pb}$ levels were based on Scheffé's method for testing differences among means applied to logarithmically-transformed values to ensure normal distributions of data (Sokal \& Rohlf 1981). Comparisons of other biophysical parameters throughout this study were based on the $95 \%$ confidence intervals of means.

Quality control. To minimize contamination, all glassware in contact with the samples and standard was soaked in $7 \mathrm{~N} \mathrm{HNO}_{3}$ for a minimum of $48 \mathrm{~h}$, rinsed 3 times with DDW, stored in $2 \mathrm{~N} \mathrm{HNO}_{3}$ and rinsed again with DDW before use.

A standard reference material, oyster tissue (NBS 1566), and an internal reference consisting of $\mathrm{Pb}$ spiked calcium carbonate (Aldrich, Gold Label), were included in the analysis as quality control samples for each day's run. These standard samples were stored in a desiccator and were treated in the same manner described for the samples. The Pb levels in the internal reference was cross-checked by inductively coupled plasma-mass spectrometry (ICP-MS) using a Sciex Elan model 250. Agreement with the certified value as well as the $\mathrm{Pb}$ recoveries determined by AAS and ICPMS was good throughout. 


\section{RESULTS}

\section{Physical parameters}

The mean tidal amplitude in the study area was ca $2 \mathrm{~m}$ and hence only the mussels collected south of Belledune Harbor (Stns C1 to C4) were from the intertidal zone (Table 1). The salinity did not vary with depth and was essentially the same at all stations.

The concentrations of SPM in the coastal samples south of Belledune Harbor (C1 to $\mathrm{C} 4$ ) were similar to those collected at Dalhousie Harbor (Table 1). The amount of SPM measured within Belledune Harbor (B1 to B3) was 3 to 5 times lower than at all other sampling stations. Windy conditions prevailed throughout the $3 \mathrm{~d}$ sampling period. Consequently, the wave height in the more open areas such as Dalhousie and the coastal sites averaged ca $1.0 \mathrm{~m}$. The waters inside Belledune Harbor were sheltered from the prevailing northwest winds and the recorded wave height was never greater than $0.3 \mathrm{~m}$. Hence, calmer conditions coupled with greater sampling depths could explain the lower SPM concentrations measured within Belledune Harbor.

\section{Mussel age determination}

Acetate peel observations revealed that the mussels collected from the subtidal zone were nearly $3 \mathrm{yr}$ younger on average than similar sized mussels collected from the intertidal zone (Fig. 2). A 13-yr-old specimen was recorded at $\mathrm{C} 1$ whereas no mussels older than 8 yr were observed from the subtidal stations in Belledune and Dalhousie. The significantly $(\mathrm{p}<0.05)$ thinner growth bands in $\mathrm{C} 1$ mussels also suggested

Table 1. Depth $(\mathrm{m})$, salinity (\%), and concentration (mg $\mathrm{l}^{-1}$ ) of suspended particulate matter (SPM) at sampling stations in the study area

\begin{tabular}{|lrcl|}
\hline Station & Depth & Salinity & SPM \\
\hline D1 & 4.0 & 23 & 6.12 \\
D2 & 3.0 & 24 & 4.34 \\
D3 & 3.5 & 25 & 5.04 \\
D4 & 4.0 & 25 & 3.56 \\
D5 & 3.5 & 25 & 5.92 \\
D6 & 5.5 & 27 & 5.14 \\
D7 & 3.5 & 24 & 3.78 \\
B1 & 12.0 & 24 & 1.30 \\
B2 & 11.0 & 24 & 1.82 \\
B3 & 6.0 & 24 & 1.86 \\
C1 & 0.5 & 23 & 6.34 \\
C2 & 0.5 & 24 & 4.87 \\
C3 & 0.5 & 24 & 3.19 \\
C4 & 1.5 & 24 & 4.28 \\
\hline
\end{tabular}

slower growth rates for mussels located in the intertidal zone (Fig. 2),

\section{SPM-Pb concentrations}

The SPM-Pb contents in Table 2 have been listed as $\mathrm{Pb}$ concentrations per unit weight of $\operatorname{SPM}\left(\mu \mathrm{g} \mathrm{g}^{-1}\right)$ and by the more conventional parameter, $\mathrm{Pb}$ per unit volume of seawater ( $\mu \mathrm{g} \mathrm{l}^{-1}$ ). The latter, however, does not accurately convey the degree of contamination among the various sampling sites due to the high variability of SPM concentrations between sheltered and unsheltered sampling sites (Table 1 ).

The highest SPM Pb-concentration was recorded at the station nearest to the smelter's current outfall at Stn $\mathrm{C} 1$. Slightly lower amounts of $\mathrm{Pb}$ were measured in the Belledune Harbor samples, all of which were at least 3 times higher than those measured at Dalhousie Harbor. The SPM Pb-levels measured in the coastal stations south of Belledune Harbor ( $\mathrm{C} 1$ to $\mathrm{C} 4$ ) decreased rapidly in relation to their distance from the smelter outfall.

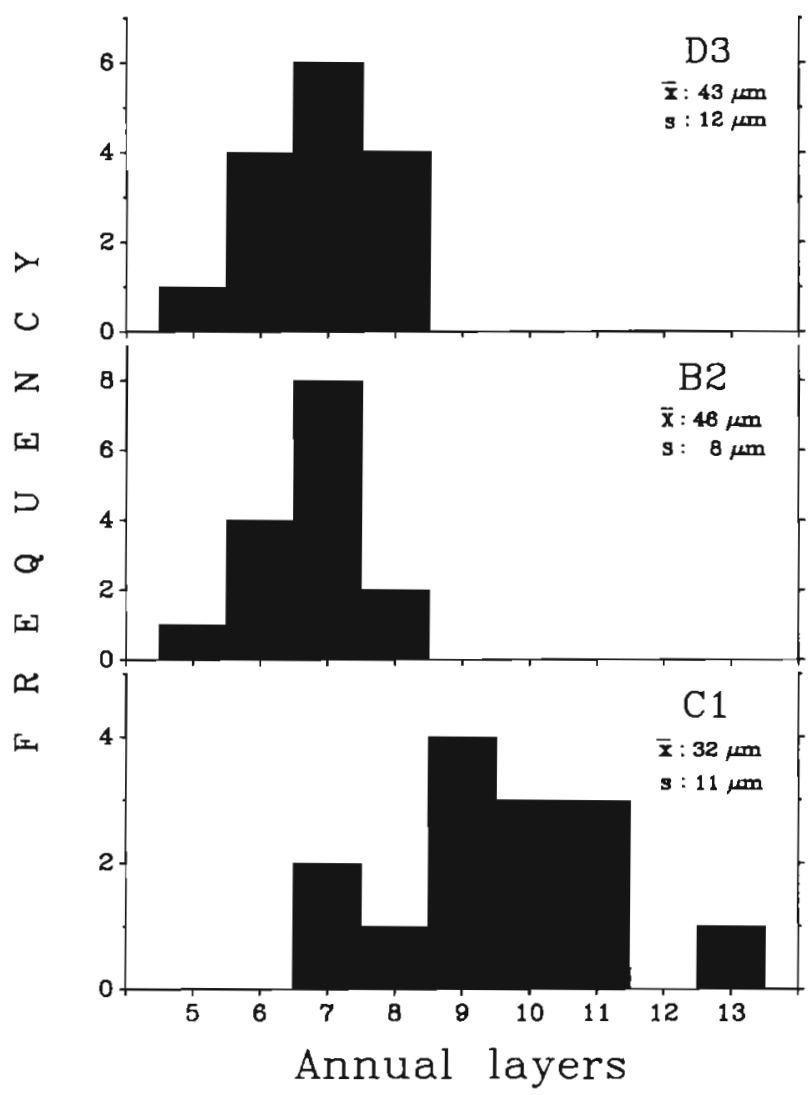

Fig. 2. Mytilus edulis. Frequency distribution of annual layers' in shells, as determined by acetate peels of longitudind valve sections ( $65 \pm 3 \mathrm{~mm}$ shell length) from selected stations in the study area. Sample size $=15$ mussels per station; $\overline{\mathrm{x}}$ : average thickness $(\mu \mathrm{m})$ of individual annual layers; $s$ : standard deviation 
Table 2. Lead concentrations measured in the tissues and nacre of Mytilus edulis and suspended particulate matter (SPM). Data for nacre and tissue are mean of 10 individual analyses. (CV) percent coefficient of variation

\begin{tabular}{|c|c|c|c|c|c|c|}
\hline \multirow[t]{2}{*}{ Station } & \multicolumn{2}{|c|}{ Tissue $\mathrm{Pb}\left(\mu \mathrm{g} \mathrm{g}^{-1}\right)$} & \multicolumn{2}{|c|}{ Nacre $\mathrm{Pb}\left(\mu \mathrm{g} \mathrm{g}^{-1}\right)$} & \multicolumn{2}{|c|}{$\mathrm{SPM} \mathrm{Pb}$} \\
\hline & Mean & $\mathrm{CV}$ & Mean & $\mathrm{CV}$ & $\left(\mu \mathrm{g} \mathrm{g}^{-1}\right)$ & $\left(\mu g 1^{-1}\right)$ \\
\hline D1 & 17.3 & $46 \%$ & 2.1 & $14 \%$ & 192.4 & 1.18 \\
\hline D2 & 12.9 & $42 \%$ & 1.0 & $20 \%$ & 241.3 & 1.05 \\
\hline D3 & 9.3 & $43 \%$ & 0.7 & $26 \%$ & 178.9 & 0.90 \\
\hline D4 & 9.3 & $35 \%$ & 0.7 & $30 \%$ & 105.0 & 3.74 \\
\hline D5 & 7.6 & $47 \%$ & 0.3 & $17 \%$ & 135.1 & 0.80 \\
\hline D6 & 8.2 & $41 \%$ & 0.4 & $27 \%$ & 162.3 & 0.83 \\
\hline D7 & 6.1 & $37 \%$ & 0.3 & $32 \%$ & 77.8 & 0.29 \\
\hline B1 & 404.4 & $43 \%$ & 27.2 & $14 \%$ & 582.1 & 0.76 \\
\hline $\mathrm{B} 2$ & 347.6 & $39 \%$ & 26.1 & $20 \%$ & 696.3 & 1.27 \\
\hline B3 & 219.2 & $44 \%$ & 13.3 & $17 \%$ & 844.0 & 1.57 \\
\hline $\mathrm{C} 1$ & 505.8 & $52 \%$ & 49.1 & $19 \%$ & 974.3 & 6.18 \\
\hline $\mathrm{C} 2$ & 249.4 & $51 \%$ & 18.6 & $16 \%$ & 387.4 & 1.89 \\
\hline $\mathrm{C} 3$ & 94.1 & $55 \%$ & 7.6 & $32 \%$ & 63.9 & 0.22 \\
\hline $\mathrm{C} 4$ & 17.4 & $59 \%$ & 1.9 & $13 \%$ & 55.2 & 0.24 \\
\hline Mean & & $45 \%$ & & $22 \%$ & & \\
\hline
\end{tabular}

In Dalhousie, samples collected nearest to the ore loading facilities yielded the highest Pb concentrations, whereas the lowest $\mathrm{Pb}$ level was recorded off the Quebec coast at Stn D7. No significant Pb gradient was observed in the remaining Dalhousie stations.

\section{Mussel-Pb concentrations}

The tissue $\mathrm{Pb}$ concentrations were ca 1 order of magnitude higher than the $\mathrm{Pb}$ levels measured in the nacre (Table 2). The $\mathrm{Pb}$ levels in both materials were significantly ( $\mathrm{p}<0.001$ ) correlated and best described by the following power equation:

$$
\mathrm{Y}=0.35 \mathrm{X}^{074}
$$

where $Y$ and $X$ represent the $\mathrm{Pb}$ concentrations in the nacre and tissues, respectively (Fig. 3).

The $\mathrm{Pb}$ concentrations in mussels collected from Dalhousie Harbor generally decreased from west to east or relative to their distance from the ore loading facilities. Mussels collected from the westernmost portion of the harbor at Stn D1 sequestered the most Pb, whereas the lowest $\mathrm{Pb}$ levels were recorded in mussels collected off the Quebec coast at D7 (Table 2).

The $\mathrm{Pb}$ levels in mussels collected from Belledune Harbor averaged 1 to 2 orders of magnitude higher than the $\mathrm{Pb}$ levels in mussels sampled from the Dalhousie region (Table 2). Tissue $\mathrm{Pb}$-levels displayed a trend of decreasing Pb-levels from B1 to B3. This gradient, however, was not reflected in the shell data which showed that mussels collected from B1 and B2 had comparable nacre-Pb levels; ca twice as high than that measured in mussels from B3.

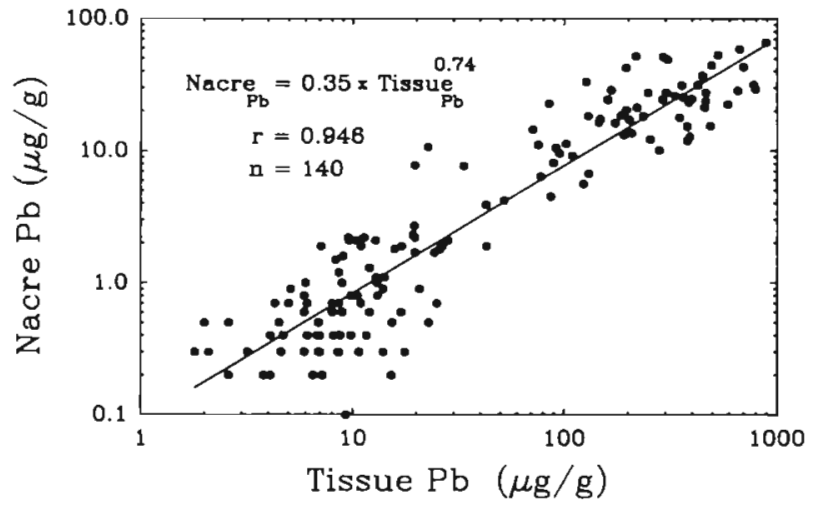

Fig. 3. Mytilus edulis. Relationship between lead concentrations ( $\mathrm{g} \mathrm{g} \mathrm{g}^{-1}$ dry wt) in the nacreous shell layers and soft tissues

The highest $\mathrm{Pb}$ concentration in either the tissues or nacre was recorded in mussels collected nearest to the current outfall, at Stn $\mathrm{C} 1$. The $\mathrm{Pb}$-concentrations in the mussels collected south of Belledune Harbor ( $\mathrm{C} 1$ to $\mathrm{C} 4$ ) decreased rapidly, similar to the SPM $\mathrm{Pb}$-concentrations (Table 2).

The statistical variability associated with the nacre$\mathrm{Pb}$ levels was approximately half that calculated for the tissues (Table 2). The coefficients of variation related to tissue- $\mathrm{Pb}$ ranged between 59 and $35 \%$ whereas the highest value attributed to nacre-Pb was only $30 \%$ and as low as $13 \%$. Although no trend was observed in the variability associated with nacre- $\mathrm{Pb}$, the largest coefficients of variance related to tissue- $\mathrm{Pb}$ consistently occurred in the mussels collected from the intertidal stations (C1 to C4). 


\section{DISCUSSION}

\section{$\mathrm{SPM}-\mathrm{Pb}$ vs mussel-Pb}

Although sessile mussels cannot avoid adverse conditions, they can stop feeding in excessively turbid water to avoid ingesting large amounts of refractory material such as sediments (Coker et al. 1921). Hence, the author feels that the absolute $\mathrm{Pb}$ concentration in the SPM, i.e. $\mu \mathrm{g} \mathrm{g}^{-1}$, better reflects the degree of contamination among the various sampling stations. Significant relationships $(\mathrm{p}<0.01)$ were obtained when mussel- $\mathrm{Pb}$ levels, i.e. tissues and nacre, were regressed to absolute SPM-Pb concentrations, $\mu \mathrm{g} \mathrm{g}^{-1}$ (Fig. 4). This illustrates the potential availability of $\mathrm{Pb}$ in the particulate phase to filter-feeding organisms. Mussels accumulate $\mathrm{Pb}$ and other trace metals from the seawater either directly from the solution, i.e. dissolved metals, or from the particulate phase. Schultz-Baldes (1974) demonstrated that $\mathrm{Pb}$ uptake by Mytilus edulis from either of these 2 routes occurred at similar rates at equal concentrations and suggested the latter route to be more important because the concentration of dissolved $\mathrm{Pb}$ is relatively much lower in coastal environments. Loring \& Prosi (1986) also observed that $\mathrm{Pb}$

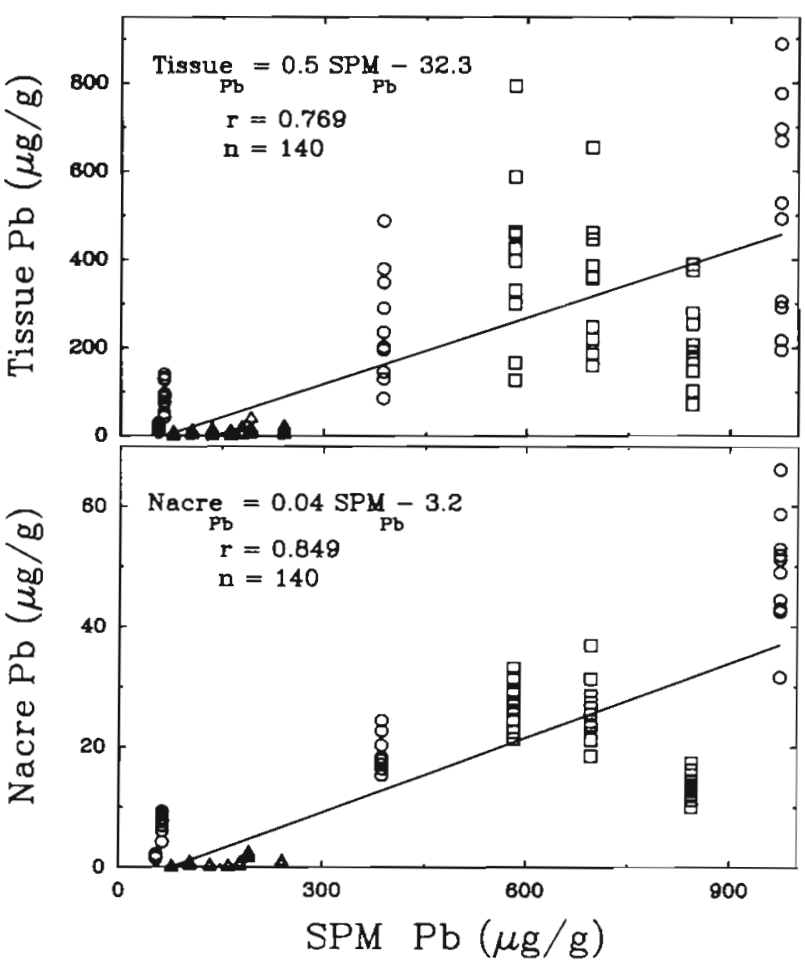

Fig. 4. Mytilus edulis. Relationship between lead concentrations ( $\left(\mathrm{g} \mathrm{g}^{-i}\right.$ dry $\left.w t\right)$ in the suspended particulate matter (SPM) and in the nacreous shell layers and soft tissues of $(\Delta)$ Dalhousie Harbor stations (D1 to DF); (口) Belledune Harbor stations (BI to B3); (o) coastal stations south of Belledune Harbor (C1 to C4) uptake by $M$. edulis was more closely related to the particulate levels.

Although the dissolved $\mathrm{Pb}$ fractions were not determined in this study, dissolved $\mathrm{Pb}$ concentrations ranging between 0.35 and $0.58 \mu \mathrm{g} \mathrm{l}^{-1}$ were observed, in 1984, within Belledune Harbor (P. A. Yates, Bedford Institute of Oceanography, pers. comm.). Based on these observations, the particulate $\mathrm{Pb}$ fractions recorded in Belledune Harbor would have accounted for 67 to $78 \%$ of the total $\mathrm{Pb}$. These estimates conform with a previous study (Levaque Charron 1981) which reported that particulate $\mathrm{Pb}$ represented at least $73 \%$ of the total $\mathrm{Pb}$ in the seawater in Belledune Harbor.

The mussel-Pb levels in specimens collected from Dalhousie Harbor plotted in Fig. 4 fell below the general relationship suggesting a lower bioavailability of the particulate $\mathrm{Pb}$ within this region. Tessier \& Campbell (1987) have demonstrated that the chemical speciation of $\mathrm{Pb}$ is an important factor in determining its bioavailability. Others (Ray et al. 1981) have shown that the $\mathrm{Pb}$ and other sedimentary trace metals near Dalhousie Harbor had a lower bioavailability because much of it occurred as sulphide. Conversely, the $\mathrm{Pb}$ levels recorded in the coastal mussels downcurrent of Belledune Harbor generally occurred above the curve in Fig. 4. This difference in the bioavailability of $\mathrm{Pb}$ between Dalhousie and Belledune may have been further accentuated because of the different point sources in these 2 regions. Ferguson (1983) observed that $\mathrm{Pb}$ compounds from smelter effluent were labile or weakly complexed and displayed a higher bioavailability. The high Pb-levels measured in mussels collected near the relocated outfall (C1) suggest that the smelter effluent continued to be a main source of contamination. In fact, the tissue-Pb measurements at Stn C1 were comparable to tissue $\mathrm{Pb}$-levels recorded in mussels receiving untreated effluent within Belledune Harbor, in 1980 (Levaque Charron 1981).

The rapidly decreasing SPM-Pb gradient observed at coastal stations south of Belledune Harbor illustrates how the particulate matter efficiently scavenges $\mathrm{Pb}$ from solution. Others (Loring et al. 1980) have similarly reported that SPM-Cd and $\mathrm{Zn}$ concentrations at Belledune decreased rapidly away from the harbor such that background levels were encountered within $4 \mathrm{~km}$ of the harbor. Ward et al. (1986) have also reported that $\mathrm{Pb}$ and $\mathrm{Cd}$ levels in biota and sediments decrease exponentially with increasing distance from a $\mathrm{Pb}$ smelter in South Australia.

\section{Nacre-Pb levels as an index of bioavailability}

The higher $\mathrm{Pb}$ levels detected in the tissues relative to the nacre conform with other studies which reported 
tissue- $\mathrm{Pb}$ concentrations 1 to 2 orders of magnitude higher than in the shells of bivalves (Segar et al. 1971, Frazier 1975). The substantial coefficient of determination obtained in Fig. $3\left(\mathrm{R}^{2}=91 \%\right)$ illustrates how the $\mathrm{Pb}$ in the tissues and nacre are strongly inter-related. Phillips (1980) previously suggested that if the adsorption of metals were non existent, the integration of metals into bivalve shells during their synthesis should occur in simple proportion to the amounts of the contaminants in the soft parts.

The fact that other authors (Romeril 1971, Bryan \& Uysal 1978) have not obtained such agreement between metals levels in whole shells and tissues suggests that the adsorption of metals to exposed shell surfaces is a highly significant parameter in determining metal levels in outer shell layers, but not in the tissues. Sturesson $(1976,1978)$ observed that ca $75 \%$ of the $\mathrm{Pb}$ and $\mathrm{Cd}$ in Mytilus edulis shells were passively adsorbed onto the periostracum.

\section{Variability associated with tissue- and nacre-Pb levels}

The variance associated with the tissue- $\mathrm{Pb}$ levels (Table 2) was within the range of those reported in previous studies (Lobel et al. 1982, Martincic et al. 1987). Although the variability in the metal levels between mussels due to extrinsic factors e.g. season, salinity, mussel size, can generally be eliminated by careful collecting techniques, a considerable amount of unexplained residual variability, or inherent variability, often persists. Body weight fluctuations related to the reproductive (Ritz et al. 1982) and/or to the physiological (Luten et al. 1986) state of the bivalves are chiefly responsible for the high variability inherent to tissue analysis. Body weight fluctuations related to the biological state of mussels, i.e. mature vs senescent, may also be an important source of variability in larger mussels. Jörgensen (1976) observed that losses of soft body weight may occur prior to death in the largest Mytilus edulis. In the case of metals with long biological half-lives e.g. $\mathrm{Pb}$, the tissue-metal levels in senescent organisms may be artificially increased due to the loss of tissue mass but the retention of the metal itself.

This problem is usually circumvented by restricting the metal analyses to bivalves of a standard size, i.e. shell length, under the assumption that bivalves within a size class are more or less all of the same age. Results from age determinations (Fig. 2) demonstrated however, that substantial age differences occurred within the size class chosen in this study. Based on a total of 45 specimens, the age of mussels within the $65 \mathrm{~mm}$ size ranged between 5 and 13 yr. Mussels collected from the intertidal zone, which reportedly have a slower growth rate than those in the subtidal zone (Baird \&
Drinnan 1957), encompassed the highest age span, i.e. $7 \mathrm{yr}$. It was also within this particular mussel group in which the highest degree of tissue- $\mathrm{Pb}$ variability was recorded (Table 2). Therefore, it is possible that mussels differing in biological state were not distinguished and may have significantly contributed to the high tissue-Pb variability. Others (Ritz et al. 1982) have previously suggested restricting metal analyses to smaller size classes of mussels.

Shell weight, as compared to tissue weight, is not as readily affected by the biological state of mussels. Fischer (1983) noted that in very large Mytilus edulis, i. e. total shell weight $>10 \mathrm{~g}$, soft-tissue growth ceased whereas shell secretion continued. This may explain why the higher variability associated with tissue- $\mathrm{Pb}$ in mussels collected from the intertidal stations was not reflected in the nacre. The fact that shell weight is much less variable than tissue weight could explain the overall decrease in the variance of nacre- $\mathrm{Pb}$ as compared to that in the tissues. Fischer (1983) demonstrated that the trace metal variability in $M$. edulis could be significantly reduced by introducing shell weight as an independent variable in relation to the amount of trace metal in soft tissues. Koide et al. (1982) suggested that the relatively uniform pumping of metals from the soft tissue to the new shell may further lower the variability associated to shell trace metal analyses.

\section{Site discrimination based on mussel-Pb levels}

The reduced variability associated with nacre-Pb would explain why it provided a better spatial resolution on the degree of $\mathrm{Pb}$ contamination among the various sampling sites as compared to the tissue- $\mathrm{Pb}$ levels (Fig. 5). A total of 5 significantly different ( $p$ $<0.05$ ) groups were defined based on the tissue- $\mathrm{Pb}$ levels, i.e. Groups a to e, whereas 3 additional groups were obtained when using nacre-Pb levels, i.e. Groups $\mathrm{g}$ to $\mathrm{h}$.

Aside from Stn C4, the 2 main groupings as defined by tissue- $\mathrm{Pb}$ levels essentially represented mussels collected either from the Belledune (a to c) or the Dalhousie ( $\mathrm{d}$ to e) region (Fig. 5). Tissue- $\mathrm{Pb}$ levels in mussels collected nearest to the current smelter outfall (C1) could not be distinguished from mussels collected at 2 stations within Belledune Harbor (B1, B2). No significant difference was established among any of the mussels collected within Belledune Harbor even though the mussels collected at B1 sequestered approximately twice the amount of $\mathrm{Pb}$ than mussels gathered from B3. These findings conform with a previous study (Gordon et al. 1980) which reported that considerably larger sample sizes were required to yield 


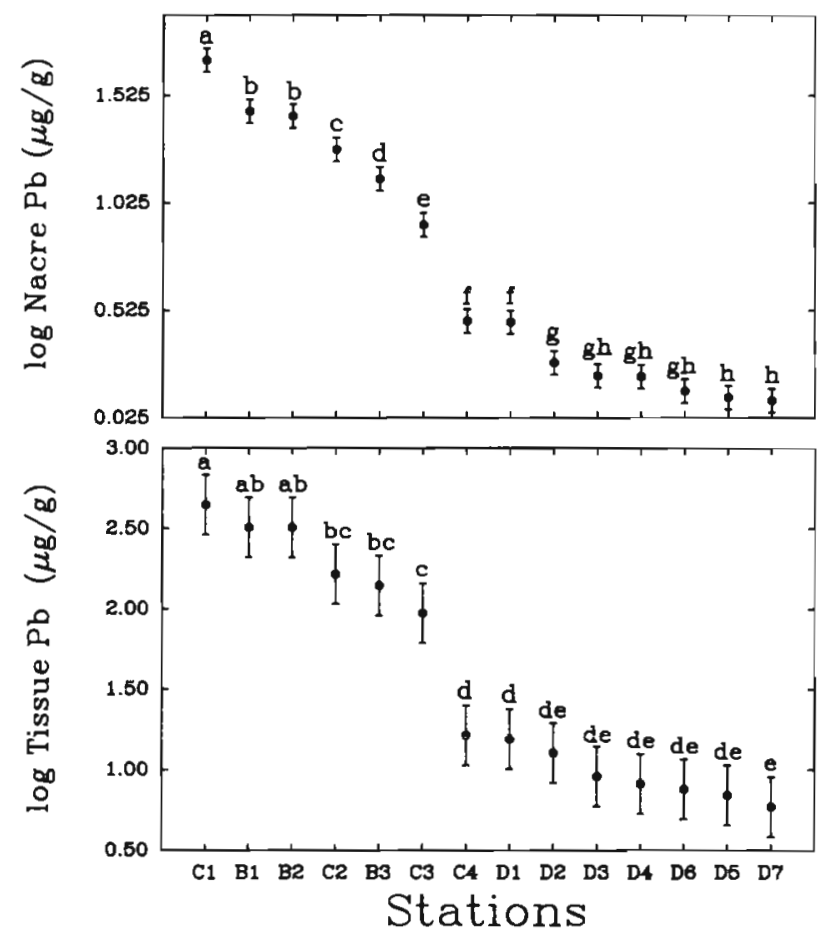

Fig. 5. Mytilus edulis. Means of log-transformed lead concentrations ( $\mu \mathrm{g} \mathrm{g}^{-1} \mathrm{dry} \mathrm{wt}$ ) in nacreous shell layers and soft tissues of specimens sampled in the study area $(10$ analyses per station). Vertical bars delimit $95 \%$ confidence limits. Bars are labelled by the same letter when means are not significantly different $(P>0.05$; Scheffé's method for testing differences among means, Sokal \& Rohlf 1981)

maximum resolution for tissue trace-metal concentrations among different sampling sites. The significantly lower $\mathrm{Pb}$ uptake in mussels collected from Stn B3 was related to higher sedimentary-P levels encountered at this station (Bourgoin et al. 1989).

Based on nacre-Pb levels, mussels collected nearest to the outfall at $\mathrm{C} 1$ were significantly different from those sampled within Belledune Harbor (Fig. 5). Furthermore, significantly different mussel groups could be defined within Belledune Harbor (B1, B2 vs B3). Koide et al. (1982) also noted that mussel shells were more sensitive to environmental trace metal levels, e.g. lower variability, than the tissues. Except for the mussels collected at D1 which displayed more affinity toward those collected at C4, no significant difference was established among any of the mussels collected at Dalhousie Harbor.

\section{FUTURE PROSPECTS OF SHELL ANALYSES}

This study demonstrates that $\mathrm{Pb}$ levels in nacre from adequately subsampled shells of Mytilus edulis do provide an index of bio-availability. Furthermore, site discrimination based on nacre- $\mathrm{Pb}$ concentrations is gener- ally improved because of the reduced variability. However, as nacre-Pb levels are generally 1 order of magnitude lower than tissue- $\mathrm{Pb}$, monitoring programs in less contaminated sites may be restricted to tissue analysis. In this instance, variability may possibly be reduced either by reporting the tissue- $\mathrm{Pb}$ content, i.e. $\mu \mathrm{g} \mathrm{Pb}$ musse $\mathrm{l}^{-1}$ or by normalizing this value by a less variable parameter, such as shell weight (Fischer 1983), rather than soft body weight.

Aside from the obvious advantages associated with shell analyses such as by-passing depuration times and refrigeration of the samples, there is another powerful aspect of shell use in monitoring studies that has yet to be thoroughly explored. Bivalve shells have already proven useful in reconstructing the historical trace metal levels over tens (Lindh et al, 1988), hundreds (Carell et al. 1987) or even thousands of years (Bourgoin \& Risk 1987). These studies, however, were limited to trace metal variations within the shells and could not circumspect on what may have been the corresponding tissue-metal levels. However, after defining the metal's fractionation between the shell and tissues, such as was done in this study (Fig. 3), historical tissue- $\mathrm{Pb}$ levels could be estimated from nacre-Pb levels measured in discrete 'annual layers' and compared with data from previous monitoring reports carried out in the same locality. Results from my study area are currently being compiled and will be reported in a separate paper (Bourgoin unpubl.).

It has recently been noted that the progress in monitoring studies may depend on identifying specific pathways and storage sites of metals in molluscs (Fischer 1988). It is not known as of yet if shell analyses will equally apply to other non-essential metals e.g. Cd, Hg. However, I suggest other trace metals would follow a similar pattern and in this respect the deposition of metals in shells should be given renewed attention.

Acknowledgements. The author thanks M. J. Risk (McMaster University), M. R. Carriker (University of Delaware), and G. Krampitz (Bonn University) for their stimulating ideas and critical comments during the preparation of the manuscript. Appreciations to P. B. Lobel (Memorial University) for his suggestions on the statistical treatment and P. A. Yates (Bedford Institute of Oceanography) for supplying the data on dissolved lead. Logistical support for this project was provided by the Department of Fisheries and Oceans (Bedford Institute of Oceanography). Primary funding was provided by the Natural Science and Engineering Research Council of Canada.

\section{LITERATURE CITED}

Baird, R. H. Drinnan, R. E. (1957). The ratio of shell to meat in Mytilus as a function of tidal exposure. J. Cons. perm. int. Explor. Mer 22: 329-336

Borg, H., Edin, A., Holm, K., Sköld, E. (1981). Determination of 
metals in fish livers by flameless atomic absorption spectroscopy. Wat. Res. 15: 1291-1295

Bourgoin, B. P. (1988). A rapid and inexpensive technique to separate the calcite and nacreous layers in Mytilus edulis shells. Mar envirl Res. 25: 125-129

Bourgoin, B. P., Risk, M. J. (1987). Historical changes in lead in the eastern Canadian Arctic, determined from fossil and modern Mya truncata shells. Sci. total Envir 67. 287-291.

Bourgoin, B. P., Risk, M. J., Aitken, A. E. (1989). Possible effect of sedimentary phosphorus on the accumulation of lead in Mytilus edulis. Bull. envir Contamn. Toxic. 43: 635-640

Bryan, G. W., Uysal, H. (1978). Heavy metals in the burrowing bivalve Scrobicularia plana from the Tamar Estuary in relation to environmental levels. J. mar biol. Ass. U.K. 58 : $89-108$

Carell, B., Forberg, S., Grundelius, E., Henrikson, L., Johnels, A., Lindh, U., Mutvei, H., Olsson, M., Svardstrom, K. Westermark, T. (1987). Can mussel shells reveal environmental history. Ambio 16: 2-10

Chétail, M., Krampitz, G. (1982). Calcium and skeletal structures in molluscs: concluding remarks. Malacologia 22: $337-339$

Coker, R. E., Shira, A. F., Clark, H. W., Howard, A. D. (1921). Natural history and propagation of freshwater mussels. Bull. Bur. Fish., Wash. 37: 75-181

Comfort, A. (1949). Acid-soluble pigments of shells. Biochem. J. $44: 111-117$

Ferguson, J. (1983). Concentrations and speciation of lead, zinc and cadmium in seawater-like smelter effluent and adjacent marine environments, Port Pirie, South Australia. Aust. J. mar. Freshwat. Res. 34: 375-385

Frazier, J. M. (1975). The dynamics of metals in the American oyster Crassostrea virginica. I. Seasonal effects. Chesapeake Sci. 16: 162-171

Fischer, H. (1983). Shell weight as an independent variable in relation to cadmium content of molluscs. Mar. Ecol. Prog. Ser 12: 59-75

Fischer, H. (1988). Mytilus edulis as a quantitative indicator of dissolved cadmium. Final study and synthesis. Mar Ecol. Prog. Ser. 48: 163-174

Gordon, M., Knauer, G. A., Martin, J. H. (1980). Mytilus californianus as a bioindicator of trace metal pollution: variability and statistical considerations. Mar Pollut. Bull. 11: 195-198

Hildebrand, L. P. (1984). An assessment of environmental quality in the Baie des Chaleurs. Environmental Protection Service Report Series (Atlantic Region), \#EPS-5-AR-848, $191 \mathrm{pp}$.

Jörgensen, C. B. (1976). Growth efficiencies and factors controlling size in some mytilid bivalves, especially Mytilus edulis: a review and interpretation. Ophelia 15: 175-192

Keckes, S., Ozretic, B., Krasnovic, M. (1968). Loss of ${ }^{65} \mathrm{Zn}$ in the mussel Mytilus galloprovincialis. Malacologia 7: 1-6

Kennish, M. J., Lutz, R. A., Rhoads, D. C. (1980). Preparation of acetate peels and fractured sections for observation of growth patterns within the bivalve shell. In: Rhoads, D. C., Lutz, R. A. (eds.) Skeletal growth of aquatic organisms. Plenum Press, New York, p. 597-606

Koide, M., Lee, S. D., Goldberg, E. D. (1982). Metal and transuranic records in mussel shells, byssal threads and tissues. Estuar cstl Shelf Sci. 15: 679-695

Krampitz, G., Graser, G. (1988). Molecular mechanisms of biomineralization in the formation of calcified shells. Angew. Chem. 27: 1145-1156

Legendre, L., Watt, W D. (1970). The distribution of primary production relative to a cyclonic gyre in Baie des Chaleurs. Mar. Biol. 7 : 167-170
Levaque Charron, R. L. (1981). Marine environmental impact survey of the Belledune Harbor area, New Brunswick, for the period May, 1979, to April, 1980. Noranda Research Centre, Internal Report No. 389

Lindh, U., Mutvei, H. Sunde, T., Westermark, T (1988). Environmental history told by mussel shells. Nucl. Instr Meth. B30: 388-392

Lobel, P. B., Mogie, P., Wright, D. A., Wu, B. L. (1982). Metal accumulation in four molluscs. Mar. Pollut. Bull. 13: $170-174$

Loring, D. H., Bewers, J. M., Seibert, G., Kranck, K. (1980). A preliminary survey of circulation and heavy metal contamination in Belledune Harbour and adjacent areas. In: Uthe, J. F., Zitko, V (eds.) Cadmium pollution of Belledune Harbour, New Brunswick, Canada. Can. Tech. Rep. Fish. Aquat. Sci. 963: 35-47

Loring, D. H., Prosi, F. (1986). Cadmium and lead cycling between water, sediment, and biota in an artificially contaminated mud flat on Borkum (F.R.G.). Wat. Sci. Tech. 18: 131-139

Luten, J. B., Bouquet, W., Burggraf, M. M., Rauchbaar, A. B., Rus, J. (1986). Trace metals in mussels (Mytilus edulis) from the Waddenzee, Coastal North Sea and the estuaries of Ems. Toxicol. 36: 770-777

Lutz, R. A. (1976). Annual growth patterns in the inner shell layer of Mytilus edulis L. J. mar. biol. Ass. U.K. 56: $723-731$

Lutz, R. A., Rhoads, D. C. (1980). Growth patterns within the molluscan shell. In: Rhoads, D. C., Lutz, R. A. (eds.) Skeletal growth of aquatic organisms. Plenum Press, New York, p. 203-254

Martincic, D., Kwokal, Z., Branica, M. (1987). Trace metals in selected organisms from the Adriatic Sea. Mar. Chem. 22: $207-220$

Phillips, D. J. H. (1980). Quantitative aquatic biological indicators. Applied Science Publishers, Barking

Rantala, R. T. T., Loring, D. H. (1977). A rapid determination of 10 elements in marine suspended particulate matter by atomic absorption spectrophotometry. At. Abs. Newslett. 16: $51-52$

Ray, S., MicLeese, D. W., Peterson, M. R. (1981). Accumulation of copper, zinc, cadmium and lead from two contaminated sediments by three marine invertebrates - a laboratory study. Bull. envir. Contam. Toxic. 26: 315-322

Ritz, D. A., Swain, R., Elliott, N. G. (1982). Use of the mussel Mytilus edulis planulatus (Lamarck) in monitoring heavy metal levels in seawater. Aust. J. mar. Freshwat. Res. 33: 491-506

Romeril, M. G. (1971). The uptake and distribution of ${ }^{65} \mathrm{Zn}$ in oysters. Mar. Biol. 9: 347-354

Schulz-Baldes, M. (1974). Lead uptake from seawater and food, and lead loss in the common mussel, Mytilus edulis. Mar Biol. 25: 177-193

Segar, D. A., Collins, J. D., Riley, J. P. (1971). The distribution of the major and some minor elements in marine animals II. Molluscs. J. mar. biol. Ass. U.K. 51: 131-136

Simkiss, K., Wilbur, K. M. (1977). The molluscan epidermis and its secretions. Symp. zool. Soc. Lond. 39: 35-76

Sokal, R. R., Rohlf, F. J. (1981). Biometry. W. H. Freeman \& Co., New York

Spurr, A. K. (1969). A low viscosity epoxy resin embedding medium for electron microscopy. J. Ultrastruct. Res. 26: 31

Sturesson, U. (1976). Lead enrichment in shell of Mytilus edulis. Ambio 5: 253-256

Sturesson, U. (1978). Cadmium enrichment in shell of Mytilus edulis. Ambio 7: 122-125

Taylor, J. D., Kennedy, W. J., Hall, A. (1969). The shell struc- 
ture and mineralogy of the Bivalvia. Introduction. Nuculea-Trigonacea. Bull. Br. Mus. nat. Hist. (D: Zool.) 3: $1-125$

Tessier, A., Campbell, P. G. C. (1987). Partitioning of trace metals in sediments: relationships with bioavailability. Hydrobiologia 149: 43-52

Ward, T. J., Correll, R. L., Anderson, R. B. (1986). Distribution

This article was presented by $\operatorname{Dr} C$. D. Levings, West Vancouver, B.C., Canada of cadmium, lead and zinc amongst the marine sediments, seagrasses and fauna, and the selection of sentinel accumulators, near a lead smelter in South Australia. Aust. J. mar. Freshwat. Res. 37: 567-585

Wilbur, K. M., Saleuddin, A. S. (1983). Shell formation. In Wilbur, K. M. (ed.) The Mollusca - physiology. Vol. 4. Academic Press, New York, p. 235-237

Manuscript first received: May 12, 1989

Revised version accepted: January 4, 1990 